\title{
Long-chain class III metallothioneins as a mechanism of cadmium tolerance in the marine diatom Phaeodactylum tricornutum Bohlin
}

\author{
E. Torres, A. Cid, P. Fidalgo, C. Herrero, J. Abalde, ${ }^{1}$
}

Aquatic Toxicology, Volume 39, Issues 3-4, November 1997, Pages 231-246

Received 3 March 1997, Accepted 20 April 1997, Available online 3 February 1998

DOI: 10.1016/S0166-445X(97)00034-9

\begin{abstract}
Cadmium tolerance of the marine diatom Phaeodactylum tricornutum Bohlin was studied. $P$. tricornutum growth was significantly reduced by cadmium concentrations of $5 \mathrm{mg} \mathrm{l}-1$ or higher. The EC50 value was $22.39 \mathrm{mg} \mathrm{I}^{-1}$ of cadmium after four days of exposure. Therefore, $P$. tricornutum is more tolerant to cadmium than other microalgal cells. In response to exposure to cadmium, $P$. tricornutum synthesize class III metallothioneins which sequester the metal in a harmless form. However, cadmium tolerance of $P$. tricornutum cells is not only due to the ability of this microalga to synthesize class III metallothioneins ( $\gamma$-Glu-Cys)n-Gly, but also because these metallothioneins are composed of long-chain polypeptides. The cadmium-metallothionein complexes of $P$. tricornutum cells contain predominantly polypeptides of $n=4-9$. Long-chain metallothioneins are more efficient in binding heavy metals. Capillary electrophoresis was used to separate class III metallothioneins. This is a recent technique used to separate many molecules. With this technique, the length of the separated polypeptides can also be estimated.
\end{abstract}

\section{Keywords}

Microalga; Cadmium; Tolerance; Class III metallothioneins

\section{Introduction}

High levels of heavy metals can be toxic to marine phytoplankton (Brand et al., 1986). Because tolerance is one of the most important mechanism for survival, many organisms respond to the cytotoxic effects of heavy metals by synthesizing metal-chelating proteins or peptides. The predominant class of such molecules in algae are class III metallothioneins (Robinson, 1989).

Cadmium has been recognized as one of the most toxic aquatic contaminants. Evidence that microalgal cadmium tolerance is achieved by metal-chelating peptides was obtained with Euglena

\footnotetext{
${ }^{1}$ Laboratorio de Microbiologia, Facultad de Ciencias, Universidad de A Coruña, Campus da Zapateira s/n, 15071 A Coruña, Spain
} 
gracilis (Gingrich et al., 1984). Recent studies show that these molecules are produced by microalgal species from several classes (Gekeler et al., 1988: Robinson, 1989: Ahner et al., 1995).

Class III metallothioneins are polypeptides with the amino acid structure (y-Glu-Cys) ${ }_{\mathrm{n}}$-Gly, where $n$ ranges from 2 to 11 depending on the species. These molecules bind metal ions by thiolate coordination, yielding intracellular metal complexes thatcontribute to the detoxification. The class III metallothionein response pathway in microalgae constitutes a cadmium detoxification system analogous to the metallothioneins in plants (Steffens, 1990).

Metallothioneins production is enhanced when organisms are exposed to high concentrations of a wide range of metals, but cadmium was found to be the most effective inducer. The synthesis of these molecules is successively catalysed by an enzyme called phytochelatin synthasa with glutathione as a precursor. This enzyme is strictly dependent on metal activation with cadmium being the best activator (Grill et al., 1985).

Several protocols, including gel filtration chromatography followed by measurement of the metal and $\mathrm{SH}$ concentrations, arc available to detect metal binding complexes in crudc extracts of plant cells (Rauser, 1990).

Most or the studies concerning metallothioneins production in phytoplankton consist of determining the ability of these organisms to synthesize these molecules, but little information is available on the length of the induced peptides (Gekeler et al. 1988). The different lengths of the metallothioneins are characteristic of the species as well as the relative level of the individual peptides. Therefore, the length of the mctallothionein-polypeptides affects to their ability to detoxify metals.

HPLC techniques with pre- or post-column thiol groups derivatization can be used to separate the polypeptides (de Knecht et al.. 1994). Actually, capillary electrophoresis is a technique that can be used to separate many molecules with good results.

Capillary electrophoresis techniques have been extensively used for the separation of peptides or different characteristics (Beijersten and Westerlund, 1993), including class I metallothioneins (Virtanen et al. 1996). It has been demonstrated in many cases in peptide research that these techniques arc better than HPLC in separation efficiency (Gaus et aL 1993).

In this study, the ability of the marine diatom Phaeodactylum tricornutum Bohlin to synthesize class III metallothioneins in response to cadmium is assayed. A capillary electrophoresis technique was used to separate and identify the class III metallothioneinpolypeptides. This analysis indicates the mechanism that makes this microalga more tolerant to higher concentrations of cadmium than other microalgae.

\section{Material and methods}

\subsection{Effect of cadmium on growth}

$P$. tricornutum cells were cultured in batch conditions in natural organic-free seawater to determine the effect of cadmium on growth. The seawater was passed through a $0.45-\mu m$-pore Millipore filter and a charcoal column to eliminate organic chelating substances, and sterilized at 
$121^{\circ} \mathrm{C}$ for $20 \mathrm{~min}$. The assay was carried out in this raw, unenriched seawater with no inorganic nutrients added. The salinity of seawater was $350 / 00$ and the initial pH of the culture was 8.2.

Stock solution of cadmium was prepared by dilution of $\mathrm{CdCl}_{2}$ in Milli-Q water to a final concentration of $10 \mathrm{~g} \mathrm{I}^{-1}$ of $\mathrm{Cd}^{2+}$. For the experiment, appropriate volumes of the stock solution were added to the raw seawater to obtain cadmium concentrations of 1, 5, 10, 25, 50, 75 and 100 $\mathrm{mg} \mathrm{I}^{-1}$. Control cultures without cadmium were also included.

Cultures were carried out in triplicate in KIMAX test tubes containing $40 \mathrm{ml}$ of seawater. The tubes were previously rinsed with nitric acid and rinsed several times with Milli-Q water. Initial cell density was $25 \times 10^{4}$ cells $\mathrm{ml}^{-1}$. Cultures were maintained at $18 \pm 1^{\circ} \mathrm{C}$ and $68 \mu \mathrm{E} \mathrm{m}^{-2} \mathrm{~S}^{-1}$, with a dark :light cycle of 12: $12 \mathrm{~h}$ for 4 days.

Cultures were gently shaken every day to ensure homogeneous exposure to the metal. Growth of the microalgal cultures was measured daily by counting culturealiquots in a Neubauer haemocytomiter. Growth rates were calculated from these data and expressed as doublings day-I. The $\mathrm{EC}_{50}$ value (effective concentration: concentration of cadmium which reduces the population growth to $50 \%$, of the control growth level) was calculated by the method of probit analysis (Finney, 1964).

\subsection{Metallothioneins induction experiment}

\subsubsection{Culture conditions}

In contrast with the growth experiment, the induction metallothioneins assay was carried out in seawater enriched with inorganic nutrients as described by Fabregas et al. (1986) but without EDTA and Tris. Cultures were carried out in glass bottles (PYREX) with $500 \mathrm{ml}$ of culture medium and were continuously bubbled with natural sterile air at a flow rate of $10 \mathrm{I} \mathrm{min}^{-1}$. Initial cell density was $1 \times 10^{6}$ cells mll$l^{-1}$. Cultures were maintained at $18 \pm 1^{\circ} \mathrm{C}$ and $68 \mu \mathrm{E} \mathrm{m} \mathrm{m}^{-2} \mathrm{~S}^{-1}$, with a dark:light cycle of 12:12 $\mathrm{h}$. These culture conditions were necessary in order to obtain better growth, since higher amounts of biomass are required to detect and purify metallothioneins.

The cadmium concentration used for metallothioneins induction was $20 \mathrm{mg} \mathrm{l}^{-1}$. Cultures without cadmium were included as control.

\subsubsection{Detection of non-protein thiol-rich compounds in crude extracts}

Non-protein thiol-rich compounds were determined in acid crude extracts by the method of Ellman (Ellman, 1959). Cells from cultures non-exposed to cadmium and exposed to $20 \mathrm{mg} \mathrm{l}^{-1}$ were collected by centrifugation ( $4000 \mathrm{Xg}$ for $5 \mathrm{~min}$ ) and washed with metal-free seawater. The cell pellet was resuspended in $0.1 \mathrm{~N} \mathrm{HCl}$ and the cells were homogenized with an ultrasonic cell disrupter for $3 \mathrm{~min}$ at 14 microns. Unbroken cells and cellular debris were removed by centrifugation at $12000 \mathrm{Xg}$ for $15 \mathrm{~min}$ at $4^{\circ} \mathrm{C}$.

$400 \mu \mathrm{l}$ of the acid extract were mixed with $700 \mu \mathrm{l}$ of a solution containing $10 \mathrm{mM}$ DTNB (dithiobisnitrobenzoic acid, Ellman reagent) and $1 \mathrm{mM}$ EDT $\mathrm{A}$ in $0.5 \mathrm{M}$ sodium phosphate buffer, $\mathrm{pH}$ 7.5. After 2 min of reaction, the absorption was recorded at $412 \mathrm{~nm}$. Values were corrected for the absorbance of the reactives and of the extracts. 
Glutathione was used as a suitable calibrating substance for quantitating the thiols.

\subsubsection{Purification of metallothionein complexes}

Alkaline extracts from cells exposed to $20 \mathrm{mg} \mathrm{l}^{-1}$ of cadmium for 10 days and from cells nonexposed to cadmium were prepared. Cells were collected by centrifugation ( $4000 \mathrm{Xg}$ for $5 \mathrm{~min}$ ) and washed with metal-free seawater. The cellular pellet was resuspended in $75 \mathrm{mM}$ sodium borate buffer, pH 8.6, and the cells were disrupted and clarified as in the acid extracts.

$1 \mathrm{ml}$ of these alkaline extracts were applied to a Biogel P-60 (Bio-Rad) gel permeation column (2.5 X $60 \mathrm{~cm}$ ) equilibrated with $75 \mathrm{mM}$ sodium borate buffer, $\mathrm{pH}$ 8.6. The extracts were eluted at room temperature $\left(23 \pm 2^{\circ} \mathrm{C}\right)$ in the same buffer at a flow rate of $0.4 \mathrm{ml} \mathrm{min}^{-1}$. The absorption of the eluates were monitored at $254 \mathrm{~nm}$ and fractions of $4 \mathrm{ml}$ were collected.

The metallothioneins-containing fractions in the extract from cells exposed to cadmium were located by cadmium analysis and by measurement of the thiol content of an aliquot of each fraction. Cadmium was measured by atomic absorption spectroscopy and thiol groups by the method of Ellman (Ellman, 1959).

\subsection{Analysis of metallothioneins}

\subsubsection{Determination of amino acid content of metallothionein complexes}

The purified fraction containing the highest concentration of cadmium and thiol groups was analyzed to determine the amino acid composition. Because cysteine is an important amino acid in the composition of metallothioneins, this amino acid must be stabilized before hydrolysis, since it is susceptible to oxidation during this procedure. An alternative method described by Barkholt and Jensen (1989) was used. Stabilization can be achieved using 3,3' -dithiodipropionic acid (DTDPA) which reacts with cysteine to form a stable molecule under hydrolysis conditions.

Aliquots from the purified fraction were mixed with a solution containing 10\% DTDPA dissolved in borate buffer $(0.4 \mathrm{~N}, \mathrm{pH} 10.4)$. After $1 \mathrm{~h}$, the hydrolysis was made by addition of Hel and phenol at final concentrations of $6 \mathrm{~N}$ and $0.5 \%$, respectively. The tube containing the mixture was sealed and hydrolysed for $24 \mathrm{~h}$ at $110^{\circ} \mathrm{C}$. The tube was then cooled and the sample was evaporated to dryness. Finally, the sample was reconstituted in the borate buffer and centrifuged at $12000 \mathrm{~g}$ for $10 \mathrm{~min}$ at $4^{\circ} \mathrm{C}$.

The amino acids were, analysed by HPLC after derivatization with OPA (o-phthaldialdehyde) for primary amino acids and FMOC (9-fiuorenylmethylchloroformate) for secondary amino acids using a $\mathrm{C}_{18}$ ODS Hypersil $5 \mu \mathrm{m}(250 \times 4 \mathrm{~mm})$ column equipped with a guard column Lichrospher 100RP-18, $5 \mu \mathrm{m}(4 \times 4 \mathrm{~mm})$,

Chromatographic procedure (Godel et al., 1991):

Eluent A: $20 \mathrm{mM}$ sodium acetate $\mathrm{pH}$ 7,2/0.3\% tetrahydrofuran/0,018\%) triethylamine.

Eluent B: 100 mM sodium acetate $\mathrm{pH}$ 7.2/acetonitrile/methanol 20/40/40 
Time (min)

0

17

18

18.5

28

28.2

30

Detection by fluorescence:

primary amino acids (OPA): secondary amino acids (FMOC):
$\% B$

0

60

100

100

100

100

0

exc $340 \mathrm{~nm}$

$\operatorname{exc} 266 \mathrm{~nm}$
Flow $\left(\mathrm{ml} \min ^{-1}\right)$

1.63

1.63

1.63

2.5

2.5

1.63

1.63

em $450 \mathrm{~nm}$ em $305 \mathrm{~nm}$

Results were compared with those obtained for glutathione and a correction factor was applied based upon values obtained for the amino acid content of glutathione.

\subsubsection{Analysis of metallothioneins by capillary electrophoresis}

The fraction containing the highest concentration of class III metallothioneins was analysed by capillary electrophoresis.

Table I

Final cell densities and growth rates $(\mu)$ of $P$. tricornutum cells exposed to different cadmium concentrations for 4 days

\begin{tabular}{|c|c|c|c|c|c|c|c|c|}
\hline \multicolumn{9}{|c|}{ Cadmium concentrations/mg $\mathrm{I}^{-1}$} \\
\hline & Control & 1 & 5 & 10 & 25 & 50 & 75 & 100 \\
\hline $\begin{array}{l}\text { Final cell } \\
\text { density } \\
\left(\times 10^{-1} \mathrm{cls} \mathrm{ml}^{-1}\right)\end{array}$ & 101.63 & 100.14 & 88.43 & 58.88 & 40 & 33.1 & 26.24 & 25.2 \\
\hline $\begin{array}{l}\mu \\
\left(\text { doublings day }^{-1}\right)\end{array}$ & 0.658 & 0.646 & 0.568 & 0.392 & 0.199 & 0.091 & $\sim 0$ & $\sim 0$ \\
\hline
\end{tabular}




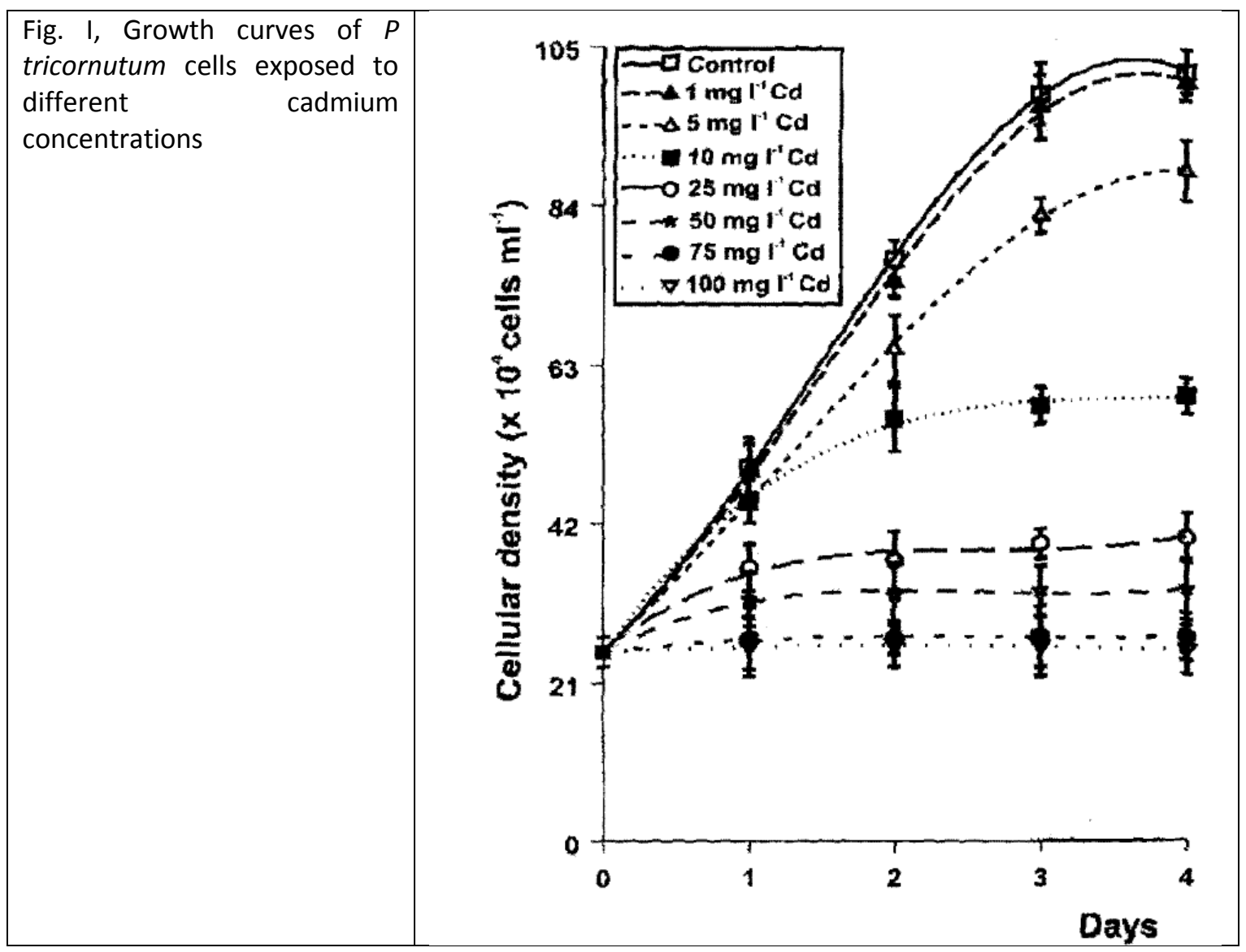

The electrophoretic analysis was performed on a Waters Quanta 4000 CapiHary Electrophoresis System equipped with a positive high-voltage power. The capillary was uncoated fused silica, 50 $\mu \mathrm{m}$ I.D., total length $37 \mathrm{~cm}$ (30 $\mathrm{cm}$ to the detector). UV detection was fixed at a wavelength of $214 \mathrm{~nm}$ Injection was hydrostatic.

Prior to the runs, the capillary was rinsed with I M sodium hydroxide solution, distilled water, $1 \mathrm{M}$ $\mathrm{HCl}$, and then conditioned for 3 minutes with the separation buffer. The running buffer was phosphoric acid. $150 \mathrm{mM}$, Between each injection, the capillary was consecutively washed for 2 min with $0.1 \mathrm{M} \mathrm{HCl}$ and Milli-Q water to remove surface-adhered material and to maintain separation reproducibility, and finally the capillary was filled with running buffer. The sample was introduced at the anode by gravity at a height of $15 \mathrm{~cm}$. The analysis was performed by applying a $+10 \mathrm{kV}$ voltage in a constant voltage mode and at room temperature $(23 \pm 2 " \mathrm{C})$. 


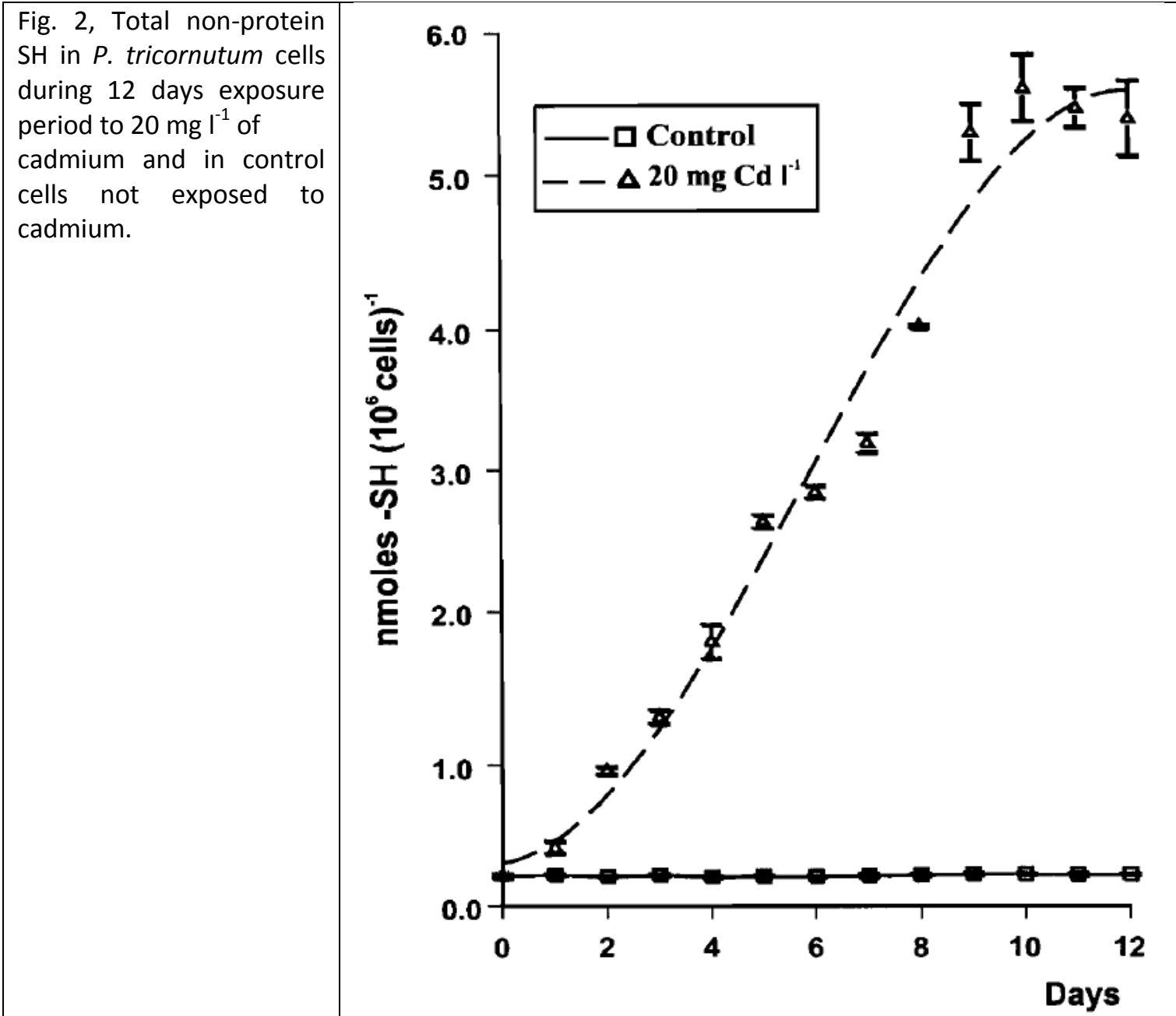

Before injection, the samples were treated with $\mathrm{NaBH} 4$ at a final concentration of $2 \mathrm{mM}$ to break the possible S-S bridges formed while the samples were not injected.

\section{Results}

\subsection{Growth}

Fig. 1 shows the growth curves of $P$. tricornutum with different cadmium concentrations. Data were analyzed statistically by ANOVA and the Duncan test $(\alpha=0.05)$. The statistical analysis showed that there was a significant effect on growth of $P$. tricornutum at cadmium concentrations $\geq 5 \mathrm{mg} \mathrm{I}^{-1}$. There were no significant differences between control cultures without cadmium, and cultures with $1 \mathrm{mg} \mathrm{l}^{-1}(\mathrm{P}<0.01)$. But as cadmium concentration increased in the medium, the growth decreased. Control cells and cells exposed to 1 and $5 \mathrm{mg} \mathrm{I}^{-1}$ of cadmium reached the stationary phase in three days, whereas the cells exposed to 10 and $25 \mathrm{mg} \mathrm{I}^{-1}$ of cadmium reached the stationary phase in two days, and in the cultures with $50 \mathrm{mg} \mathrm{l}^{-1}$ of cadmium this phase is reached in only one day. Cultures with 75 and $100 \mathrm{mg} \mathrm{I}^{-1}$ did not grow at all. 

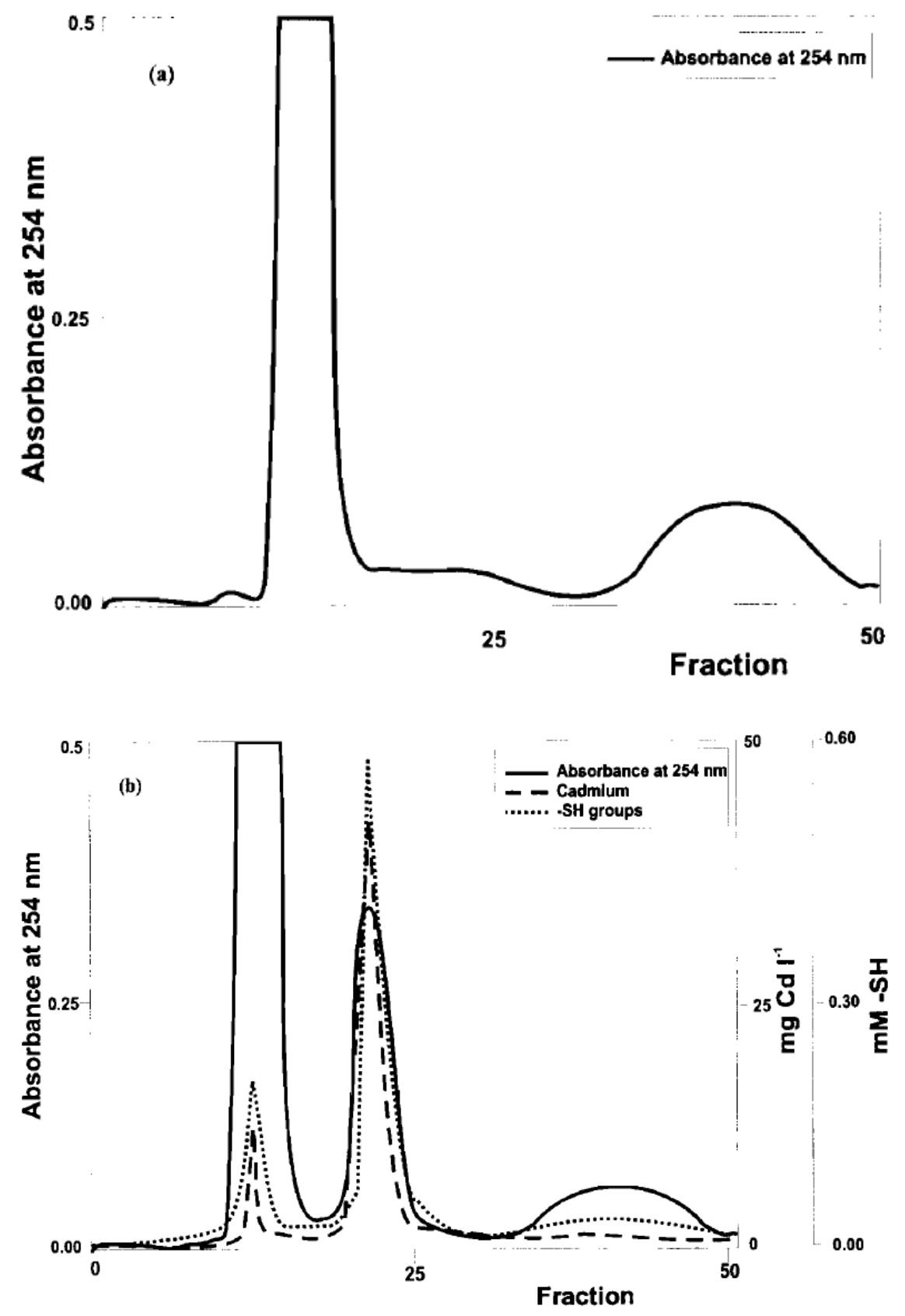

Fig. 3. Elution profile of gel permeation chromatography on Biogel P-60 of crude extracts from $P$. tricornutum cells untreated (al and treated with $20 \mathrm{mg} \mathrm{I}^{-1}$ of cadmium for 10 days (b).

Table 2

Amino acid analysis of thiol-rich fraction purified by gel permeation chromatography and of gluta* thione

\begin{tabular}{lcrrr}
\hline Amino acid/nmol mi & & & \\
& Glycine & Glutamic acid & Cysteine & Gly:Glu:Cys \\
\hline Glutathione & 72.884 & 73.012 & 69.369 & $1.00: 1.00: 0.95$ \\
Fraction & 56.398 & 270.434 & 231.297 & $1.00: 4.79: 4.10$ \\
\hline
\end{tabular}

In the absence of cadmium (control) and in cultures with $1 \mathrm{mg} \mathrm{I}^{-1}$ of cadmium, P. tricornutum cells had a higher growth rate than cells exposed to the higher cadmium concentrations. The growth 
rates decreased as cadmium concentration in the medium increased. Final cell density also showed this same pattern (Table I). The toxic effect of the different cadmium concentrations on $P$. tricornutum growth can be arranged as (Duncan test):

control $=1<5<10<25<50<75=100$

The $\mathrm{EC}_{50}$ value calculated for this microalga after 4 days exposure to this metal was $22.39 \mathrm{mg} \mathrm{I}^{-1}$ of cadmium.

\subsection{Non-protein thiols}

The time-course of thiol groups is shown in Fig. 2. The concentration of thiol groups increased with time in P. tricornutum cells exposed to cadmium, whereas thiol contents in the cells not exposed to cadmium did not change during the experiment. In cells exposed to cadmium, thiol concentration versus time fitted a sigmoidal curve with $r^{2}=0.99$. In the first day, the increase in thiol groups was low but then there was a rapid increase, reaching the highest concentration in 10 days, with 5.61 \pm 0.23 nmoles-SH $\left(10^{6} \text { cells }\right)^{-1}$.

Therefore, $P$. tricornutum cells exposed to cadmium are able to synthesize and accumulate compounds with thiol groups. Cells cultured in the presence of this metal accumulate an amount of non-protein thiol compounds significantly higher than that of non-exposed cells.

\subsection{Purification of metallothioneins}

The highest content of thiol groups in the cells was obtained after 10 days of exposure to $20 \mathrm{mg} \mathrm{l}^{-1}$ of cadmium (Fig. 2); for this reason, this time of exposure was chosen for the purification of metallothioneins.

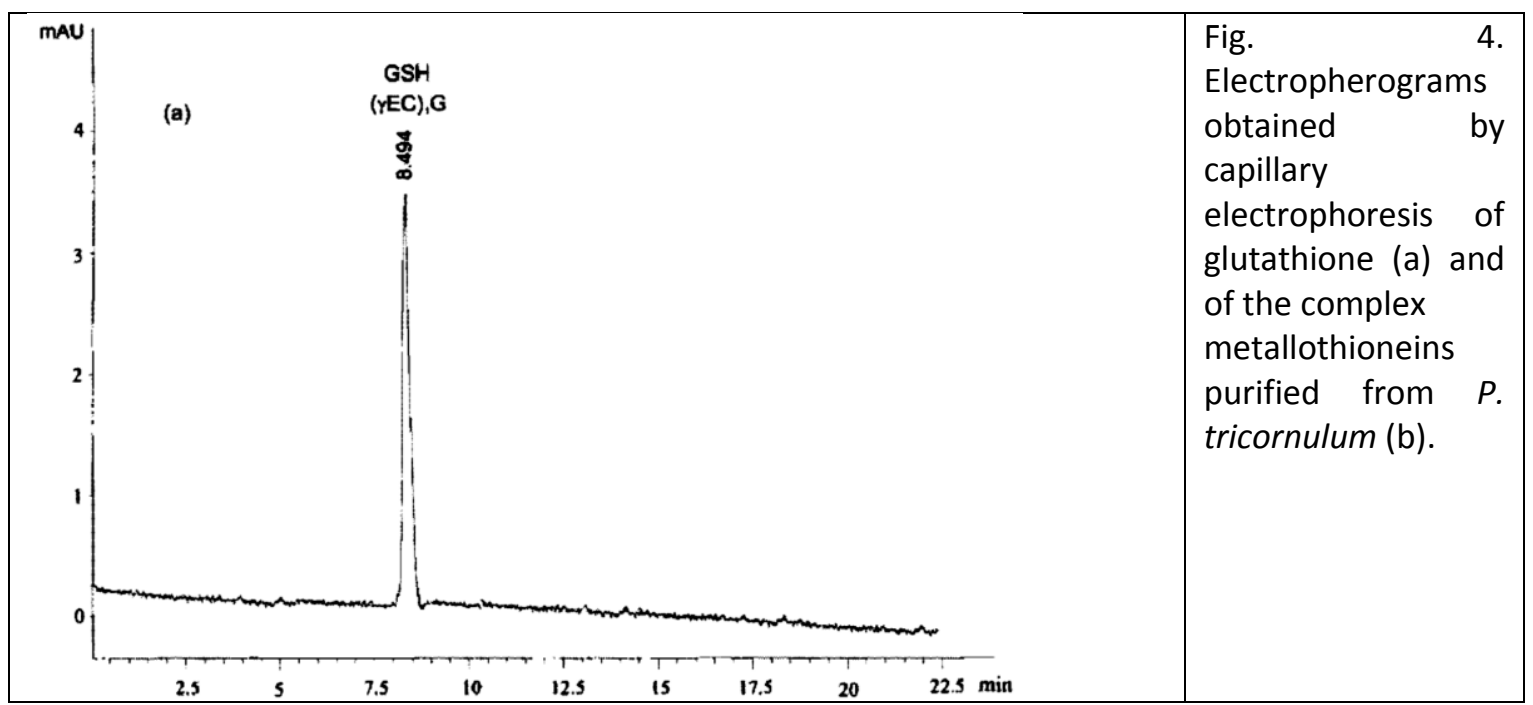




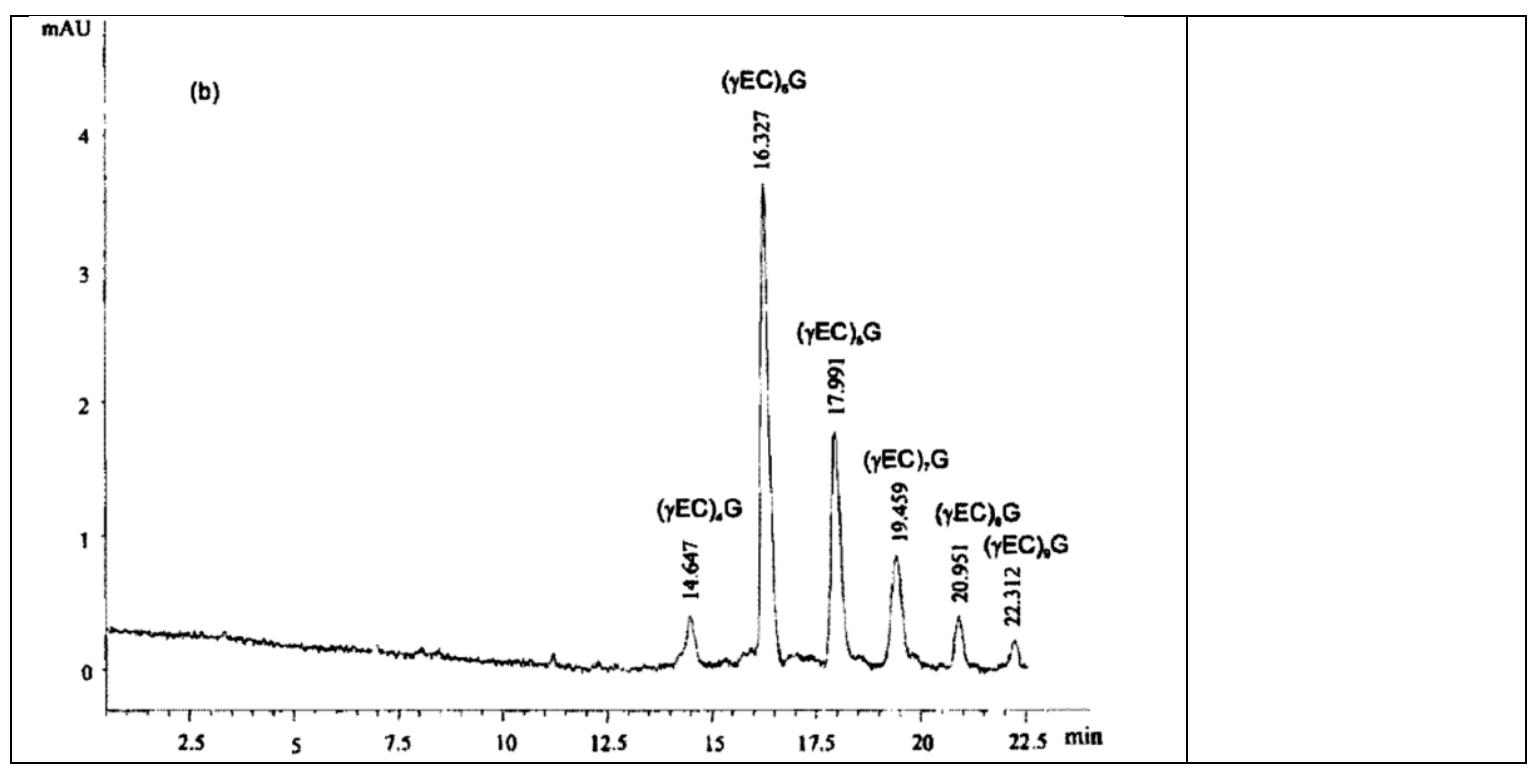

Alkaline crude extracts from $P$. tricornutum cells exposed to $20 \mathrm{mg} \mathrm{I}^{-1}$ of cadmium for 10 days and extracts from non-exposed cells were chromatographed on a gel permeation column. The obtained chromatograms are represented in Fig. 3. In the chromatogram from cells exposed to cadmium (Fig. 3b), there is a new peak that did not appear in the chromatogram of control cells (Fig. 3a). This peak has a high UV absorbance at $254 \mathrm{~nm}$, indicating the presence of metal-thiolates. Furthermore, the analysis of cadmium and thiol 5 content indicated that the fractions of this peak had the higher concentration of cadmium and thiol groups (Fig. 3b).

Metal analysis showed that about $63.71 \%$ of the cadmium in the extract applied to the column was associated with this peak. The remaining cadmium eluted in the void volume, possibly associated with proteins of high molecular weight. The highest concentration of thiol groups was also found in this new peak (Fig. 3b). The ratio $\mathrm{SH} / \mathrm{Cd}$ is about 1.8: 1.

This elution pattern is similar to those obtained from other microalgal cells exposed to cadmium (Gekeler et al., 1988; Reddy and Prasad, 1992).

\subsection{Melallolhioneins analysis}

\subsubsection{Amino acid composition}

Table 2 shows the amino acid analysis of the thio 1 and cadmium-rich fraction separated by gel permeation chromatography. Only 3 amino acids were detected: glycine, glutamic acid and cysteine. The result of quantitative analysis showed equimolecular amounts of glutamic acid and cysteine, both for glutathione and for the purified fraction, and the respective amount of glycine according to glutathione composition and to class III metallothionein species present in the complex.

Therefore, the material purified in the new peak corresponds to class III metallothioneins because these molecules were induced in response to cadmium exposure and they were characterized for the presence of metal-thiolates. Moreover, the amino acid composition was the same as class III metallothioneins. 
This peak containing the metallothioneins was analysed by capillary electrophoresis.

\subsubsection{Capillary electrophoresis analysis}

An analysis by capillary electrophoresis was made to characterize the thiol-containing molecules accumulated in response to cadmium. The electropherogram of Fig. 4a shows the peak corresponding to the glutathione (reference molecule), and the electropherogram of Fig. $4 \mathrm{~b}$ shows the peaks of the metallothioneins purified from $P$. tricornutum cells. The electropherogram of Fig. $4 \mathrm{~b}$ shows six peaks; each one corresponds to a metallothionein with a different chain length.

The presence of various peaks in the fraction containing metallothioneins indicates that these molecules form a complex of metallothioneins of different length. This electrophoretic technique also allows us to determine the length of the metallothionein-peptides. The use of an acid electrolyte (150 mM phosphoric acid) means that the migration of the metallothioneins depends only on their length. In acid conditions, metallothioneins do not have a negative charge, and the positive charge is equal in all of them, since the positive charge is due to the amine group of the glutamic acid. This amino acid is present in all metallothioneins as a terminal residue. Therefore. the differential migration to the cathode depends only on their different length.

If the glutathione ("metallothionein" with $n=1$ ) is used as the reference molecule, it is possible to deduce the length of the different metallothioneins purified from this microalga or from other cells.

It can be assumed that each metallothionein peak in Fig. $4 \mathrm{~b}$ differs from the next in one subunit of (y-Glu-Cys). Therefore, in these electrophoretic conditions, the difference in the retention time between two consecutive metallothioneins is due to one subunit. Taking this into account, it is possible to deduce the length of the first metallothionein present in $4 \mathrm{~b}$. Because the difference in the retention time of this first metallothionein with respect to glutathione $(n=1)$ will be $n$ times the difference between two consecutive metallothioneins. This length $(n)$ is indicated in the electropherogram Fig. 4b. P. tricomutum cells are able to synthesize metallothioneins with between four and nine subunits of (y-Glu-Cys). The most abundant polypeptide has five subunits and the larger polypeptide synthesized by P. tricornutwll is (y-Glu Cys) $)_{9}-\mathrm{Gly}$.

\section{Discussion}

Cadmium toxicity, as metal toxicity, is dependent on various environmental factors: temperature, salinity, $\mathrm{pH}$, concentration of free metal ions, metal complexation by inorganic and organic ligands. etc. (Rai et aL 1981). In order to work with a medium representative of natural conditions, raw natural organic-free seawater without addition of nutrient solution was used. In toxicological studies, the concentrations of nutrients must be reduced to realistic levels, not only to simulate natural conditions, but also because the concentration of each element in the nutrient solution may influence the heavy metals toxicity (Hornstrom, 1990). Thus, phosphate reduces heavy metals toxicity due to the formation of insoluble phosphates (Eichenberger, 1979). The presence of other metallic cations in the nutrient solution can antagonize the metal test, varying its toxicity (Stratton and Corke, 1979).

The initial cell density at the start of the test must be adapted to the medium and to the apparatus available. A medium without addition of mineral nutrients requires a low initial density to allow the growth in these conditions. Previous studies showed that in these culture conditions (without 


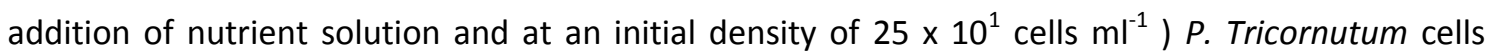
grow optimally and exponentially during 4 days (Cid et al., 1995). Several studies have been reported concerning the effect of cadmium on the growth of microalgae cells. Growth is a good indicator of the toxic action of cadmium in microorganisms and reflects the metabolism of the cell. This toxicity can be explained because this element has no known biological function. Different values of toxicity on growth were reported depending on the algal species used: Chlorella vulgaris, Chlorella saccharophila, Skeletonema costalum, Asterionella Formosa and Selenastrum capricornutum are among the most sensitive algae to cadmium, with their growth inhibited at 0.06, $0.11,0.05,0.01$ and $0.08 \mathrm{mg} \mathrm{Cd} \mathrm{I}^{-1}$ respectively (Bartlett et al., 1974; Berland et al., 1977; Rosko and Rachlin, 1977; Conway, 1978; Rachlin et al.. 1982). Conversely, Scenedesmus obliquus, Ankistrodesmus falcatus, Chlorococcum sp., Navicula incerta, Asparagotsis armata and Tetraselmis gracilis are more tolerant to cadmium, with their growth inhibited at 2.5 3.0, 2.0-2.5, 2.5-3.0, 3.01, 18.8 and $5 \mathrm{mg} \mathrm{l}^{-1}$, respectively (Cain et al., 1980; Devi Prasad and Devi Prasad, 1982; Rachlin et al., 1982; Segot et al., 1983; Okamoto et al., 1996).

P. tricornutum growth was significantly inhibited only at a concentration of $5 \mathrm{mg}$ of cadmium or higher and the $\mathrm{EC}_{50}$ value for growth was $22.39 \mathrm{mg} \mathrm{I}^{-1}$ therefore this micro alga can be included in the group of the most tolerant organisms to this metal.

The mechanisms of resistance to toxic metals for algae are varied (Maeda and Sakaguchi, 1990), but the complexation of metal ions in the cell by metal-binding compounds (class III metallothioneins) is one of the mechanisms induced by exposure to cadmium in most microalgal cells. The primary function of class III metallothioneins is thought to be metal detoxification as evidenced by the binding properties of the peptides (Weber et al., 1988). Cadmium-tolerant plant cells bind more than $80 \%$ of cellular cadmium as Cd-binding complexes (Jackson et al., 1987). Overproduction of these metal binding complexes seems to account for metal tolerance (Delhaize et al., 1989). Other evidence concerning the function of these molecules is their induction upon metal exposure and the control of phytochelatin synthasa by metal concentrations (Grill et al., 1989).

Because more biomass is required for the analysis and measurements of metallothioneins, culture conditions in the metallothioneins induction assay were different from toxicological studies. The seawater was enriched with mineral nutrients. The initial cell density and exposure time were higher, and a cadmium concentration of $20 \mathrm{mg} \mathrm{I}^{-1}$ was used for this assay because in this culture conditions the response of $P$. tricornutum cells was equivalent to a cadmium concentration of 5-10 $\mathrm{mg} \mathrm{I}^{-1}$ in the growth experiment.

Cadmium exposure caused a marked increase in the concentration of non-protein SH compounds in P. tricornutun cells (Fig. 2); therefore cadmium apparently induced the formation of these $\mathrm{SH}$ compounds. The chromatographic separation on Biogel P-60 showed that most SH compounds are located in a few fractions which have the higher cadmium concentration, forming metallic thiolates (Fig. 3).

These molecules purified from $P$. tricornutum cells grown in the presence of cadmium were shown to have the same characteristics of class III metallothioneins: therefore, the cadmium tolerance of $P$. tricornutum can be due to the ability of these microalgal cells to synthesize class IJ metallothioneins induced by this metal and to form metal-binding complexes. Different reports had 
already shown the ability of this microalga to synthesize metallothioneins (Maita et al.. 1988; Wikfors et al.. 1991), as is confirmed in the present work.

But the high tolerance to cadmium of $P$. tricornutum is not only due to the ability to synthesize class III metallothioneins, because other microalgae are also able to synthesize these molecules. In this work the capacity of $P$. Tricornutum cells to synthesize metallothioneins with long-chain polypeptides is demonstrated, showing a strategy to which these peptides constitute a cellular pathway for heavy metal tolerance. The pattern of the metallothioneins synthesized by this micro alga was determined by using a capillary electrophoresis technique.

In the present paper, the capacity of the capillary electrophoresis to separate and analyse class III metallothioneins is also demonstrated. This technique showed that $P$. tricornutum cells exposed to cadmium are able to synthesize metallothioneins with nine subunits of ( $y-G l u-C y s)$ with a main polypeptide of five subunits (Fig. 4b). This capacity is higher than that of other algae reported in the bibliography (Gekeler et al.. 1988). Chlorella fusca and Monoraphidium minutum are able to synthesize metallothioneins with six subunits. But the main polypeptides have only two and three. Stichococcus hacillaris and Navicula Pelliculosa preferably synthesize metallothioneins with two subunits. In P. tricornutum the main metallothionein polypeptide has five subunits of (y-Glu-Cys), with the larger polypeptide having nine. This capacity of synthesis allows $P$. tricornutum cells to tolerate higher cadmium concentrations than other microalgal species. Because the length of the metallothioneins affects their capacity to bind heavy metals. (y-Glu-Cys) ${ }_{5}-$ Gly is more efficient than (y-Glu-Cys) ${ }_{2}$-Gly (Loeffler et al., 1989). In this way, tomato cells with elevated cadmium tolerance also accumulate a higher proportion of larger (y-Glu-Cys) ${ }_{n}$-Gly (Gupta and Goldsbrough, 1991).

In the yeast Schyosaccharomyccs pomhe, metallothionein complexes contain acidlabile sulphideforming SCd crystallites. Incorporation of acid-labile sulphide into cadmium-metallothionein complexes may increase the Cd-binding affinity of the metallothioneins (Reese and Winge, 1988). There is also some evidence that acid-labile sulphide plays a role in the detoxification mechanism in microalgal cells exposed to cadmium (Reddy and Prasad. 1992). This mechanism also contributes to detoxification and increased cadmium tolerance. However Dameron and Winge (1990) demonstrated that peptides varying in length from $n_{1}$ (glutathione) to $n_{2}$ can act as coatings to stabilize CdS crystallites. Complexes formed with shorter peptides $\left(n_{1}\right.$ and $\left.n_{2}\right)$ are more labile, and accretion of the crystallites with larger peptides increases their stability. Therefore, in this strategy the length of the metallothionein-polypeptides also influences their ability to stabilize cadmium in the complexes.

This work shows a contribution to the mechanism of cadmium tolerance by means of class III metallothioneins in the marine diatom $P$. tricornutum, Thus, tolerance to cadmium by means of class III metallothionein synthesis can be due not only to the increase in the concentration of metallothioneins, but also to the increase in the length of the polypeptides so that more cadmium can be bound.

\section{Acknowledgements}

This study was supported by the Conselleria de Educación, Xunta de Galicia, Spain, reference XUGA 10301B93. E. Torres holds Fellowships from the Plan Nacional F.P.I. Ministerio de Educación y Ciencia, Spain. 


\title{
References
}

\author{
B.A. Ahner, S. Kong, F.M.M. Morel
}

Phytochelatin production in marine algae. 1. An interspecies comparison

Limnol. Oceanogr., 40 (4) (1995), pp. 649-657

V. Barkholt, A.L. Jensen

Amino acid analysis: determination of cysteine plus half-cystine in proteins after hydrochloric acid hydrolysis with a disulfide compound as additive

Anal. Biochem., 17 (1989), pp. 318-322

L. Bartlett, F.W. Rabe, W.H. Funk

Effects of copper, zinc and cadmium on Selenastrum capricornutum

Water Res., 8 (1974), pp. 179-185

\section{Beijersten, D. Westerlund}

Capillary electroseparations of some di-, tri-, and tetrapeptides and enkephalin-related peptides Anal. Chem., 65 (1993), pp. 3484-3488

B.R. Berland, D.J. Bonin, L.J. Guerin-Ancey, V.I. Kaplov, D.P. Arlhac

Action de métaux lourds á des doses sublétales sur les caractéristiques de la croissance chez la diatomée Skeletonema costatum

Mar. Biol. (Berl.), 42 (1977), pp. 17-30

L.E. Brand, W.G. Sunda, R.R.L. Guillard

Reduction of marine phytoplankton reproduction rates by copper and cadmium

J. Exp. Mar. Biol. Ecol., 96 (1986), pp. 225-250

J.R. Cain, D.C. Paschal, C.M. Hayden

Toxicity and bioaccumulation of cadmium in the colonial green alga Scenedesmus obliquus

Arch. Environ. Contam. Toxicol., 9 (1980), pp. 9-16

\section{A. Cid, C. Herrero, E. Torres, J. Abalde}

Copper toxicity on the marine microalga Phaeodactylum tricornutum: effects on photosynthesis and related parameters

Aquatic Toxicol., 31 (1995), pp. 165-174

\section{H.L. Conway}

Sorption of arsenic and cadmium and their effects on growth, micronutrient utilization, and photosyntetic pigment composition of Asterionella formosa

J. Fish. Res. Bd. Can., 35 (1978), pp. 286-294

C.T. Dameron, D.R. Winge

Characterization of peptide-coated cadmium-sulfide crystallites

Inorg. Chem., 29 (1990), pp. 1343-1348 
J.A. de Knecht, M. van Dillen, P.L.M. Koevoets, H. Schat, J.A.C. Verkleij, W.H.O. Ernst

Phytochelatins in cadmium-sensitive and cadmium-tolerant Silene vulgaris. Chain length distribution and sulfide incorporation

Plant Physiol., 104 (1994), pp. 255-261

E. Delhaize, P.J. Jackson, L.D. Lujan, N.J. Robinson

Poly( $($-glutamylcysteinyl)glycine synthesis in Datura innoxia and binding with cadmium tolerance

Plant Physiol., 89 (1989), pp. 700-706

P.V. Devi Prasad, P.S. Devi Prasad

Effect of cadmium, lead and nickel on three freshwater green algae

Water Air Soil Pollut., 17 (1982), pp. 263-268

E. Eichenberger

The study of eutrophication of algal benthos by essential metals in artificial rivers

O. Ravera (Ed.), Biological Aspects of Freshwater Pollution, Pergamon Press, Oxford (1979), pp. 111-128

G.L. Ellman

Tissue sulfhydryl groups

Arch. Biochem. Biophys., 82 (1959), pp. 70-77

J. Fábregas, C. Herrero, B. Cabezas, J. Abalde

Biomass production and biochemical composition in mass cultures of the marine microalga Isochrysis galbana Parke at varying nutrient concentrations

Aquaculture, 53 (1986), pp. 101-113

D.J. Finney

Probit AnalysisCambridge Univ. Press, London, U.K (1964)

H.-J. Gaus, A.G. Beck-Sickinger, E. Bayer

Optimization of capillary electrophoresis of mixtures of basic peptides and comparision with HPLC

Anal. Chem., 65 (1993), pp. 1399-1405

W. Gekeler, E. Grill, E.-L. Winnnacker, M.H. Zenk

Algae sequester heavy metals via synthesis of phytochelatin complexes

Arch. Microbiol., 150 (1988), pp. 197-202

D.J. Gingrich, D.H. Petering, C.F. Shaw III

Zinc and cadmium metabolism in Euglena gracilis: metal distribution in normal and zinc-deficient cells

Mar. Environ. Res., 14 (1984), pp. 89-102

H. Godel, P. Seitz, M. Verhoef 
Automated amino acid analysis using combined OPA and FMOC-Cl precolumn derivatization

LC-GC Intl., 5 (1991), pp. 44-49

E. Grill, S. Löffler, E.-L. Winnacker, M.H. Zenk

Phytochelatins, the heavy-metal-binding peptides of plants, are synthesized form glutathione by a specific $\gamma$-glutamylcysteine dipeptidyl transpeptidase (phytochelatin synthase)

Proc. Natl. Acad. Sci. USA, 86 (1989), pp. 6838-6842

E. Grill, E.L. Winnacker, M.H. Zenk

Phytochelatins: the principal heavy-metal complexing peptides of higher plants

Science, 230 (1985), pp. 574-576

\section{S.C. Gupta, P.B. Goldsbrough}

Phytochelatin accumulation and cadmium tolerance in selected tomato cell lines

Plant Physiol., 97 (1991), pp. 306-312

E. Hörnström

Toxicity test with algae-A discussion on the batch method

Ecotoxicol. Environ. Safety, 20 (1990), pp. 343-353

P.J. Jackson, C.J. Unkefer, J.A. Doolen, K. Watt, N.J. Robinson

Poly( $\gamma$-glutamylcysteinyl)glicine: Its role in cadmium resistance in plant cells

Proc. Natl. Acad. Sci., 84 (1987), pp. 6619-6623

S. Loeffler, A. Hochberger, E. Grill, E.-L. Winnacker, M.H. Zenk

Termination of the phytochelatin synthase reaction through sequestration of heavy metals by the reaction product

FEBS Lett., 258 (1989), pp. 42-46

\section{S. Maeda, T. Sakaguchi}

Accumulation and detoxification of toxic metal elements by algae

I. Akatsuka (Ed.), Introduction to Applied Phycology, SPB Academic Publishing, The Netherlands (1990), pp. 109-136

Y. Maita, S. Kawaguchi, K. Tada

A metallothionein-like protein induced in a diatom, Phaeodactylum tricornutum

Okaichi, Anderson, Nemoto (Eds.), Red Tides: Biology, Environmental Science and Toxicology, Elsevier Science Publishing Co., Inc (1988), pp. 345-348

O.K. Okamoto, C.S. Asana, E. Aidar, P. Colepicolo

Effects of cadmium on growth and superoxide dismutase activity of the marine microalga Tetraselmis gracilis (Prasinophyceae)

J. Phycol., 32 (1996), pp. 74-79

J.W. Rachlin, B. Warkentine, T.E. Jensen 
The growth responses of Chlorella saccharophila, Navicula inserta and Nitzschia closterium to selected concentrations of cadmium

Bull. Torrey Bot. Club, 109 (1982), pp. 129-135

L.C. Rai, J.P. Gaur, H.D. Kumar

Phycology and heavy-metal pollution

Biol. Rev., 56 (1981), pp. 99-151

W.F. Rauser

Phytochelatins

Annu. Rev. Biochem., 59 (1990), pp. 61-86

G.N. Reddy, M.N.V. Prasad

Characterization of cadmium binding protein from Scenedesmus quadricauda and Cd toxicity reversal by phytochelatin constituting amino acids and citrate

J. Plant Physiol., 140 (1992), pp. 156-162

R.N. Reese, D.R. Winge

Sulfide stabilization of the cadmium $\chi$-glutamil peptide complex of Schizosaccharomyces pombe

J. Biol. Chem., 263 (1988), pp. 12832-12835

N.J. Robinson

Algal metallothioneins: secondary metabolites and proteins

J. Phycol., 1 (1989), pp. 5-18

J.J. Rosko, J.W. Rachlin

The effects of cadmium, copper, mercury, zinc, and lead on cell division, growth and chlorophyll a content of the chlorophyte Chlorella vulgaris

Bull. Torrey Bot. Club, 104 (1977), pp. 226-233

M. Segot, E. Codomier, G. Combaut

Action de quatre métaux lourds (cadmium, cuivre, mercure, plombs) sur la croissance d' Asparagopsis armata en culture

J. Exp. Mar. Biol. Ecol., 66 (1983), pp. 41-48

J.C. Steffens

The heavy metal-binding peptides of plants

Annu. Rev. Plant Physiol. Plant Mol. Biol., 41 (1990), pp. 553-575

\section{G.W. Stratton, C.T. Corke}

The effect of mercuric, cadmium and nickel ion combinations on a blue green alga

Chemosphere, 10 (1979), pp. 731-740

V. Virtanen, G. Bordin, A.-R. Rodriguez 
Separation of metallothionein isoforms with capillary zone electrophoresis using an uncoated capillary column. Effects of $\mathrm{pH}$, temperature, voltage, buffer concentration and buffer composition J. Chromatogr., A 734 (1996), pp. 391-400

D. Weber, C.F. Shaw III, D.H. Petering

Properties of structure and function of cadmium-binding proteins/peptides from Euglena gracilis Mar. Environ. Res., 24 (1988), pp. 159-162

G.H. Wikfors, A. Neeman, P.J. Jackson

Cadmium-binding polypeptides in microalgal strains with laboratory-induced cadmium tolerance Mar. Ecol. Prog. Ser., 79 (1991), pp. 163-170 